\title{
LIFE SAFETY
}

\section{ПРОГРАМА «ЗВАРЮВАЛЬНИК》 ДЛЯ ДОСЛІДЖЕННЯ ВПЛИВУ ЧИННИКІВ ВИРОБНИЧОГО СЕРЕДОВИЩА НА ЗДОРОВ'Я ПРАЦЮЮЧОГО}

\author{
Березуцький В. В. \\ проф., д.т.н. Україна, Харків, Національний технічний університет «Харківський \\ політехнічний інститут», завідуючий кафедрою «Охорона прачі та навколишнього \\ середовища»;
}

\begin{abstract}
Хондак I. I.
Украйна, Харків, Харківський національний університет радіоелектроніки, старший викладач кафедри «Охорона прачі»
\end{abstract}

DOI: https://doi.org/10.31435/rsglobal_wos/31032020/7003

\section{ARTICLE INFO}

Received: 13 January 2020

Accepted: 10 March 2020

Published: 31 March 2020

\section{KEYWORDS}

influence,

factor,

gamification,

distance learning,

computer games,

welding.

\begin{abstract}
In today's world, gamification is widely used as one of the most effective approaches to learning. Developed and implemented in the educational process work "Welder" is a visual tool in the study of the influence of factors of the production environment and the work process on the health of the working and environment in the welding process. The use of such works in various forms of training is very important and necessary in modern conditions. This is especially true for distance learning. With distance learning, where there is virtually no "live" communication with the teacher, there are difficulties in presenting theoretical material. In connection with this, a new computer simulation program was developed and introduced into the educational process at the Department of Occupational Safety at Kharkiv National University of Radio Electronics. The program, which gives an opportunity to clearly visualize the impact of various factors on the welder and the environment, introduces methods and means of protection against their negative impact.
\end{abstract}

Citation: Березуцький В. В., Хондак I. I. (2020) Prohrama «Zvariuvalnyk» dlia Doslidzhennia Vplyvu Chynnykiv Vyrobnychoho Seredovyshcha na Zdorovia Pratsiuiuchoho. International Academy Journal Web of Scholar. 3(45). doi: 10.31435/rsglobal_wos/31032020/7003

Copyright: (C 2020 Березуцький В. В., Хондак I. I. This is an open-access article distributed under the terms of the Creative Commons Attribution License (CC BY). The use, distribution or reproduction in other forums is permitted, provided the original author(s) or licensor are credited and that the original publication in this journal is cited, in accordance with accepted academic practice. No use, distribution or reproduction is permitted which does not comply with these terms.

Вступ. В даний час в усьому світі широко використовується дистанційна форма навчання. При дистанційній формі навчання, де практично відсутнє «живе» спілкування 3 викладачем, виникають складності 3 засвоєнням теоретичного матеріалу та виконанням практичних завдань і лабораторних робіт. Застарілі підходи не забезпечують достатній рівень вивчення матеріалу та гідну оцінку отриманих знань. Стрімкий розвиток технологій вимагає від сучасних викладачів розробку нових методологій, що будуть як найкраще відповідати темпам сьогоднішніх освітніх потоків. У зв'язку 3 цим на кафедрі «Охорона праці» Харківського національного університету радіоелектроніки щорічно розробляються і впроваджуються в навчальний процес нові комп'ютерні моделюють програми, які дають можливість наочно розглядати вплив різних чинників на людину і навколишнє середовище, знайомлять 3 методами i засобами захисту від їх негативного впливу. Метою створення комп'ютерних моделей 
лабораторних робіт з дисциплін «Екологічна безпека», «Безпека життєдіяльності людини», «Основи охорони праці» є закріплення теоретичних знань за допомогою різних візуальних компонентів і засобів інформаційних технологій. Комп'ютерні моделі адекватно відображають всі фізичні процеси, досліджувані при виконанні лабораторних робіт.

Однією з таких робіт є програма «Зварювальник».

\section{Основна частина.}

В сучасних умовах питання безпеки життя і діяльності людини, а також пошук засобів захисту людини від негативних наслідків, пов'язаних з антропогенним впливом на людину і на навколишнє середовище, $є$ актуальним. На сьогоднішній день людина в повсякденному житті і в процесі трудової діяльності піддається впливу безлічі факторів, що негативно позначаються на його здоров'ї. Проблема впливу небезпечних і шкідливих чинників на працюючого викликаєзанепокоєння про стан здоров'я людини, тому особливу увагу приділяють питанням навчання молодих фахівців, студентів основам захисту від чинників небезпек.

Надзвичайно цікавим $є$ питання створення навчального комплексу, який дозволяє просімуліровать функціонування стану здоров'я працюючого під впливом техногенних факторів.

Вивчення питань, пов'язаних з методичною розробкою лабораторних і практичних робіт, на яких застосовуються комп'ютерні ігри в навчальних цілях, є одним з актуальних напрямків у дослідженні комп'ютерного навчання. Особлива увага до комп'ютерних ігор пов'язана 3 двома обставинами. По-перше, використання комп'ютера $є$ якісно новим етапом застосування гри в навчальному процесі, яка традиційно займала важливе місце поряд 3 іншими організаційними формами навчальної діяльності. По-друге, становлення і розвиток комп'ютерних ігор багато в чому пов'язано з їх величезною популярністю і широким поширенням. В даний час комп'ютерні ігри вважаються «повноправним елементом культури в епоху науково-технічної революції». Дуже важливо приділяти увагу комп'ютерним моделям, які імітують фізичні процеси, які відбуваються на виробництві і впливають на життєдіяльність людини [1].

Нормальна життєдіяльність людини вагомо залежить від умов зовнішнього середовища, зокрема виробничого. Адже в процесі трудової діяльності на організм людини чиниться своєрідний “тиск” несприятливими виробничими факторами, що прямо чи опосередковано впливає на ії здоров'я та працездатність.

Відповідно до ГОСТ 12.0.003-74 небезпечні та шкідливі фактори за природою дії поділяються на такі групи: фізичні, хімічні, біологічні та психофізіологічні.

Залежно від наслідків впливу на працюючих шкідливих та небезпечних виробничих факторів розрізняють виробничі травми, професійні захворювання та професійні отруєння, внаслідок яких може відбутись зниження або втрата працездатності (тимчасова чи постійна, повна чи часткова), можливий і фатальний кінець.

Реальні умови праці мають виключати передумови для виникнення травм та професійних захворювань. Фактори, що зумовлюють умови праці, поділяють на чотири групи

Перша група - санітарно-гігієнічні фактори - включає показники, що характеризують виробниче середовище робочої зони. Вони залежать від особливостей виробничого обладнання і технологічних процесів, можуть бути оцінені кількісно і нормовані.

Другу групу складають психофізіологічні елементи, зумовлені самим процесом праці. 3 цієї групи лише частина факторів може бути оцінена кількісно.

До третьої групи відносяться естетичні фактори, що характеризують сприйняття працюючим навколишньої обстановки та її елементів; кількісно вони оцінені бути не можуть.

Четверта група включає соціально-психологічні фактори, що характеризують психологічний клімат у трудовому колективі; кількісній оцінці також не підлягають.

Відповідно до Гігієнічної класифікації праці, затвердженої наказом МОЗ України від 08.04.2014 p. № 248, шкідливими умовами праці є стан умов праці, за якого рівень впливу одного або більше факторів виробничого середовища та/або трудового процесу перевищує допустимий.

Одним із основних технологічних процесів у багатьох галузях промисловості є зварювання та інші споріднені технології, що характеризуються шкідливими виробничими факторами, які, в свою чергу можуть призвести до нещасних випадків та професійних захворювань.

Несприятливу дію шкідливих факторів виробничого середовища на здоров'я працівників і викликані ними професійні захворювання у зварювальному виробництві можна розділити на три основні групи: 
1. Захворювання, викликані дією хімічних факторів.

2. Захворювання під дією фізичного навантаження, а також одноманітних, часто повторюваних рухів, вимушеної пози.

3. Захворювання, викликані фізичними факторами (підвищена або знижена температура повітря робочої зони, підвищений рівень шуму, ультрафіолетового, електромагнітного та інфрачервоного випромінювання).

Кожне робоче місце за умовами праці оцінюється з урахуванням впливу на працівників всіх факторів виробничого середовища і трудового процесу (фізичні, хімічні, біологічні та психофізіологічні), передбачених гігієнічною класифікацією праці.

Діагноз професійного захворювання ставиться у кожному випадку 3 урахуванням характеристики умов праці, тривалості роботи працюючого за даною професією, даних попередніх періодичних медичних оглядів, результатів клініко-лабораторних та діагностичних досліджень.

Найбільш поширеними профзахворюваннями у зварювальників $є$ захворювання дихальних шляхів: пневмоконіоз, професійний бронхіт, гіпер чутливий пневмоніт, бронхіальна астма.

Щоб робота була безпечною для осіб, безпосередньо зайнятих при процесах зварювання, i для оточуючих, слід знати можливі шкідливі і вражаючі чинники, причини їх виникнення та вміти користуватися прийомами запобігання небезпеки, засобами індивідуального і колективного захисту, щоб уникнути розвитку професійних захворювань.

Аналіз впливу шкідливих чинників виробничого середовища на організм людини.

Під час застосування різного виду зварювальних технологій може підвищуватись рівень електромагнітних полів [2,3], з'являтися лазерне, ультрафіолетове, інфрачервоне, іонізуюче випромінювання, підвищуватись напруженість електростатичного поля, рівень шуму, ультразвуку, запиленість і загазованість повітря робочої зони; можливі значні статичні навантаження на руки і плечовий пояс [3,4]. Всі ці чинники належать до шкідливих виробничих чинників (ШВЧ).

Небезпечні виробничі чинники (НВЧ), які можуть виникати при зварюванні це - вплив електричного струму, іскри і бризки, викиди розплавленого металу і шлаку; можливість вибуху балонів і систем, що знаходяться під тиском; рухомі механізми і вироби [6].Основний наголос робиться на наглядній демонстрації наслідків антропогенної діяльності людини, іiї впливу на людину і навколишнє середовище [6]. Також пропонуються методи вирішення цих питань [7].

В даній роботі будуть розглянуті і проаналізовані фізичні і хімічні фактори а саме:

• концентрація зварювального аерозолю;

- рівень шуму;

- температура повітря;

- електромагнітне випромінювання;

- ультрафіолетове випромінювання;

- інфрачервоне випромінювання.

Для зменшення впливу таких факторів і забезпечення сталості значень характеристик життєдіяльності організму включаються механізми адаптації, що дає змогу людині пристосуватися до несприятливого впливу санітарно-гігієнічних факторів (звичайно, якщо вони не виходять за певні межі). Це досягається за допомогою додаткових витрат мускульної та нервово-психічної енергії, що в свою чергу призводить до відволікання внутрішніх ресурсів працюючого від основного трудового процесу, несприятливо впливає на психофізіологічний стан людини, iї працездатність i, як наслідок, відбивається на техніко-економічних показниках підприємства.

Для того, щоб оцінити можливі наслідки впливу шкідливих чинників для виробничого процесу та для організму людини, використовують теоретичні моделі та симуляційні програми. Одним 3 різновидів таких програм є ігри симулятори, що дозволяють вивчити механізми впливу різноманітних чинників без реальних негативних наслідків. Такі програми застосовують, щоб мати змогу провести експерименти, які неможливо або занадто складно відтворити у реальному житті. Також програми такого виду можна застосовувати для навчання студентів або інструктажу робітників.

Мета роботи - розробка програмного засобу - симулятор впливу шкідливих чинників на організм зварювальника під час робочого процесу та засобів їхньої нормалізації для засвоєння та закріплення знань з охорони праці та техніки безпеки. 


\section{Дослідження чинників виробничого середовища в процесі зварювання крізь призму ігрового процесу}

Програма «Зварювальник» була розроблена для симуляції впливу шкідливих чинників на організм зварювальника під час робочого процесу та засобів їх нормалізації для засвоєння та закріплення знань з охорони праці та безпеки життєдіяльності. Програмний засіб був створений на мові C++ з використанням додаткових графічних бібліотек. Інтерфейс програми наданий на рис.1.

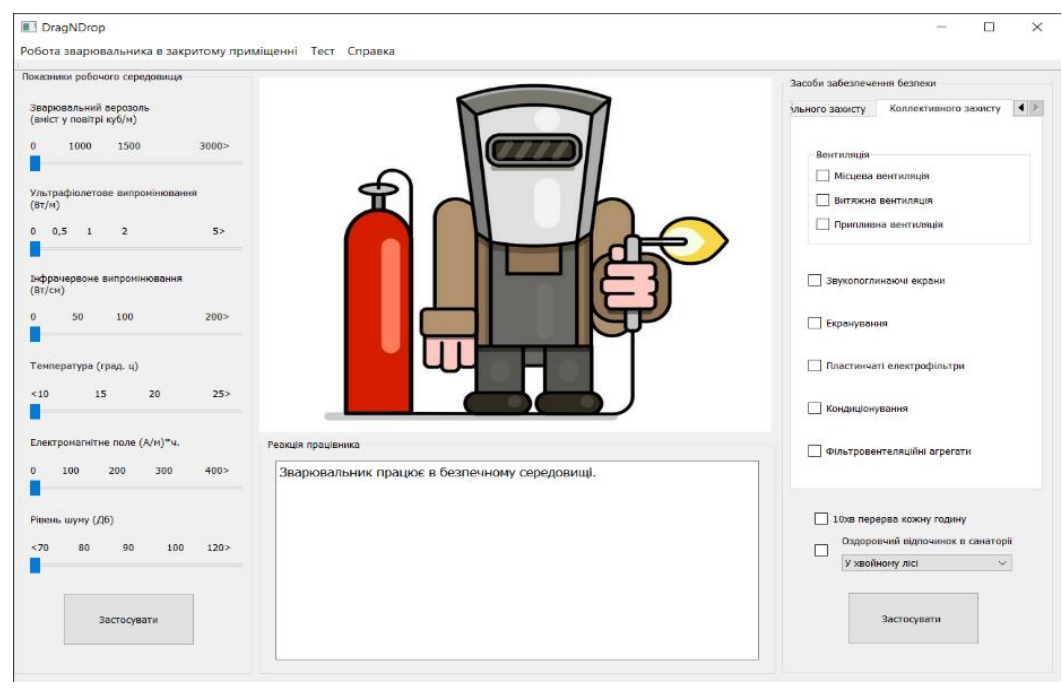

Рис.1. Інтерфейс програми «Зварювальник»

Користувача зустрічає графічний інтерфейс, на якому можна виділити три основні відділи використання програми: «Показники робочого середовища», «Засоби забезпечення безпеки» та «Реакція працівника». На верхній вкладці можна розпочати тестування для перевірки знань набутих в процесі використання програми та відкрити вкладку «Довідка» для того, щоб дізнатися про правильне використання програмного засобу, авторів програми і т.п.

Для того, щоб перевірити вплив різних показників робочого середовища на працівника необхідно, за допомогою повзунків, вказати рівні цих самих показників (рис.2). В програмі можна вказати вміст у повітрі зварювального аерозолю, рівень ультрафіолетового та інфрачервоного випромінювання, температуру в приміщенні, рівень електромагнітного поля та рівень шуму. Всі ці показники впливають на здоров'я та самопочуття працівника. Норми цих показників можна знайти на вкладці «Довідка». Далі, щоб побачити реакцію працівника, потрібно натиснути кнопку «Застосувати».

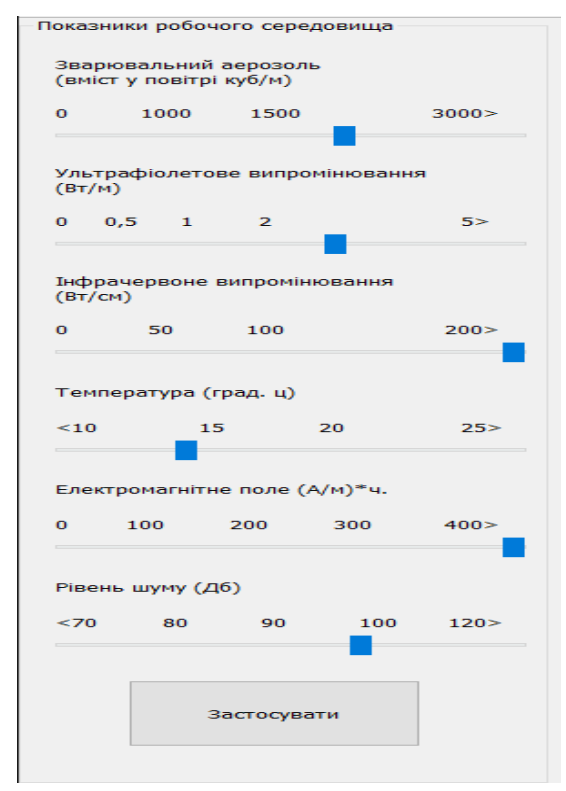

Рис.2. Показники робочого середовища 
Після цього, на панелі «Реакція працівника», можна побачити які показники є поза діапазоном норм та реакцію працівника на їх вплив (рис.3).

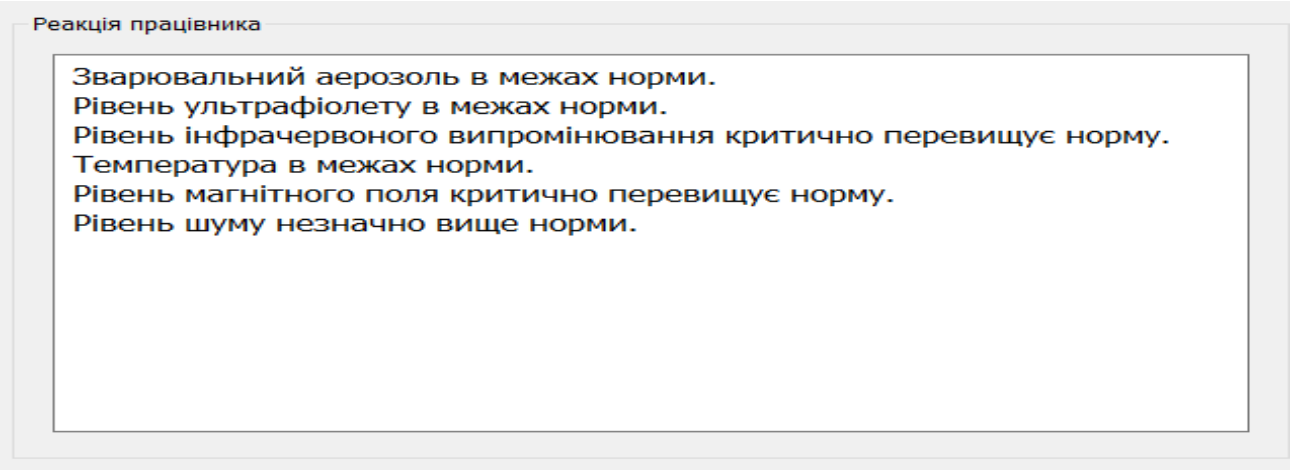

\section{Рис. 3. Реакиія працівника}

Після того, як користувач програмою отримує інформацію про стан працюючого, необхідно чинники виробничого середовища і трудового процесу привести до нормованих значень, застосовуючи необхідні заходи і засоби захисту.

\section{Заходи та засоби захисту зварювальника від впливу шкідливих чинників}

Для того щоб нормалізувати стан робочого середовища, необхідно, на панелі «Засоби забезпечення безпеки» обрати необхідні засоби захисту. Засоби захисту бувають індивідуального та колективного характеру (рис.4 та рис.5).

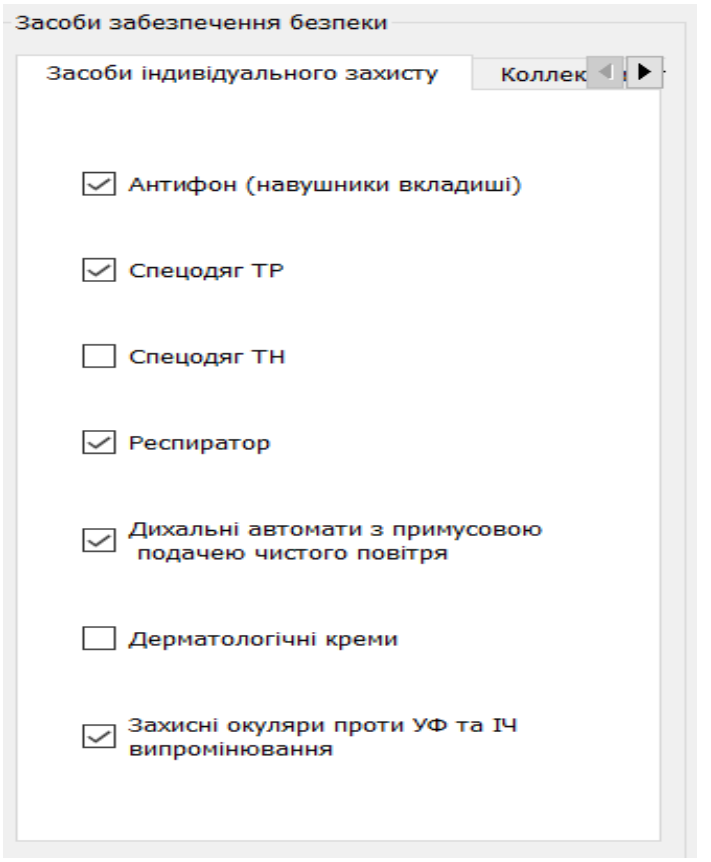

Рис. 4. Засоби індивідуального захисту

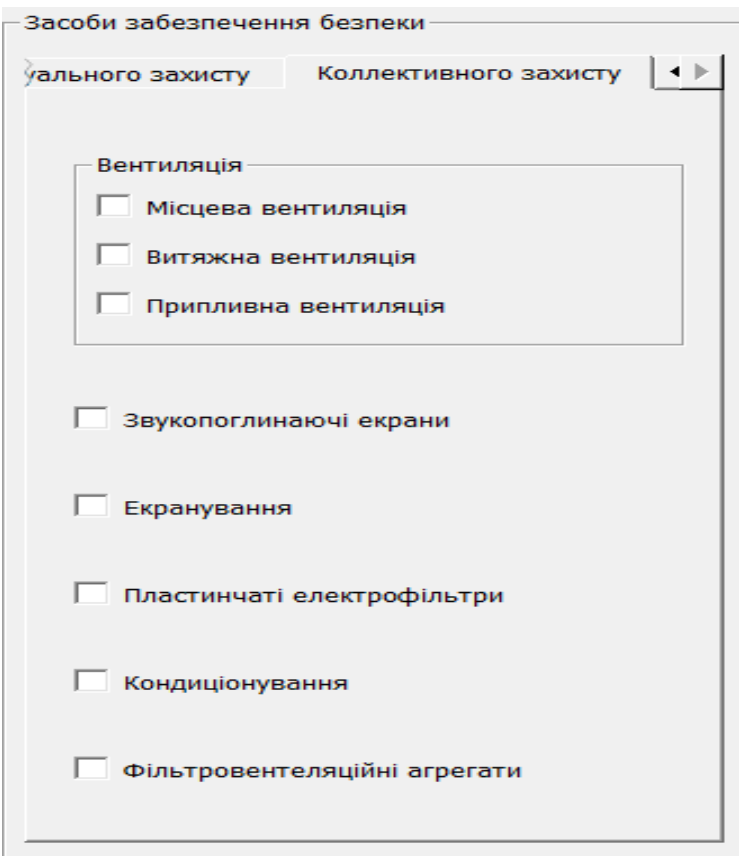

Рис. 5. Засоби колективного захисту

У перелік обов'язкових засобів, входять: маска, спеціальний костюм, взуття, рукавиці. Додатково можуть використовуватися захисні каски, щитки, протигази, респіратори, навушники, страхові системи.[15]

Ефективне застосування засобів індивідуального захисту (3ІЗ) залежить від їх правильного вибору і умов експлуатації. Також необхідно враховувати конкретні умови виробництва, вид та тривалість впливу шкідливого чинника і індивідуальні особливості людини.

Далі, на цій самій панелі можна вибрати «10хв. Перерву кожної години» та «Оздоровчий відпочинок» (рис. 6). Ці всі засоби будуть сприяти покращенню здоров'я та самопочуття працівника. 


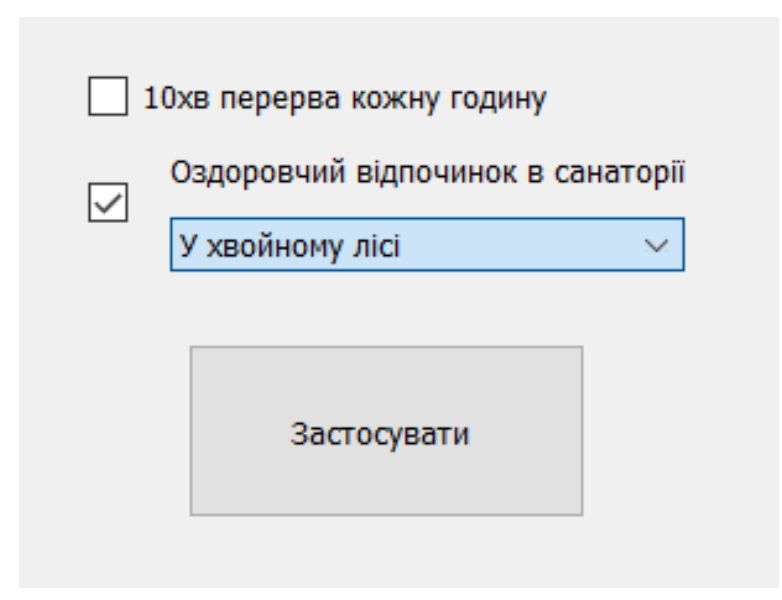

Рис.6. Додаткові засоби покращення здоров'я працівника

Після того, як всі складові були вибрані, необхідно натиснути кнопку «Застосувати». Якщо всі засоби були вибрані вірно, то на панелі «Реакція працівника» можна буде побачити, що зварювальник працює в безпечному середовищі і добре себе почуває.

Далі, коли користувач опрацює надану інформацію, він зможе пройти тест (рис.7) на знання з охорони праці та безпеки життєдіяльності натиснувши кнопку на верхній панелі.

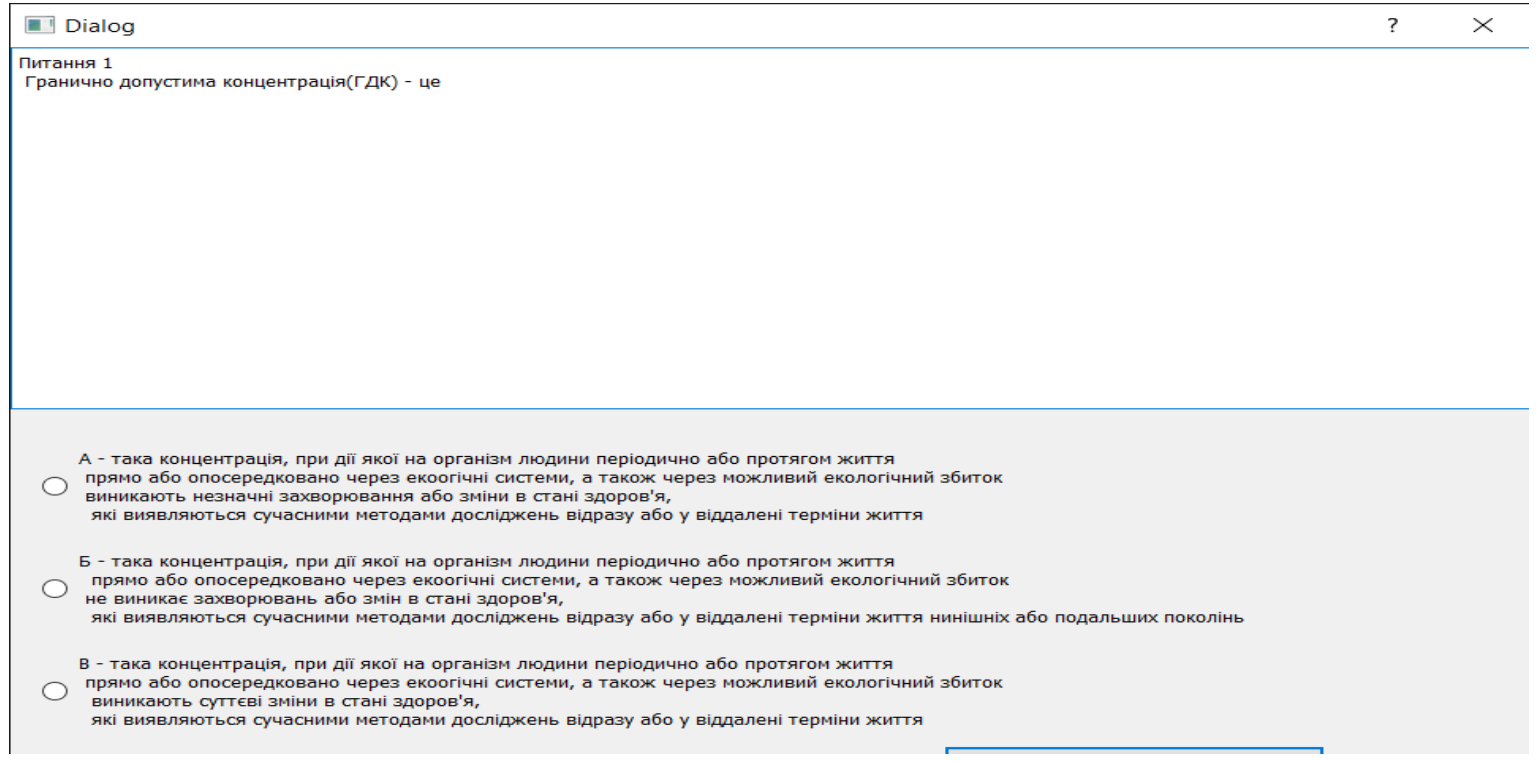

Puc.7. Tecm

Виходячи з вищевикладеного можна зробити наступні висновки:

1. Вперше була створена комп'ютерна програма 3 питань оцінки впливу шкідливих виробничих чинників в процесі зварювання, а саме рівня шуму, температури повітря робочої зони, ЕМВ, інфрачервоного випромінювання, ультрафіолетового випромінювання на зварювальника, а також запропоновані заходи щодо зменшення цього впливу.

2. При виконанні цієї роботи закріплюються теоретичні знання і набуваються практичні навички, що стосуються питань впливу шкідливих чинників виробничого середовища i трудового процесу на здоров'я зварювальника та основних заходів та засобів захисту від їх негативної дії.

3. Система тестування допоможе закріпити отриманні знання та оцінити успішність засвоєння цих знань у користувача.

4. Робота «Зварювальник» може бути використана в навчальному процесі в якості лабораторної роботи для студентів денної, заочної і дистанційної форми навчання в різних вузах України і буде цікавою для всіх, хто займається питаннями охорони праці та безпеки 
життєдіяльності, особливо процесами зварювання.Вона також може бути корисною для тренінгу спеціалістів в області захисту навколишнього середовища.

5. Реалізований підхід $є$ найсучаснішим рішенням висвітленої проблеми сучасних заходів навчання та оцінювання знань студентів ВНЗ. Використання цього підходу дозволяє автоматизувати навчальний процес, а також готує майбутнього спеціаліста до умов вирішення реальних проблем.

\section{ЛIТЕРАТУРА}

1. Березуцька Н. Л., Хондак І. І. Дослідження чинників виробничого середовища крізь призму ігрового процесу Вісник Національного технічного університету «ХПІ». Серія: Транспортне машинобудування . №29(1305). 2018. ст.157-163.

2. Березуцький В. В, Хондак I. I. Зварювання металевих виробів та безпека // Вісник Національного технічного університету "ХПІ". Сер. : Інноваційні технології та обладнання обробки матеріалів у машинобудуванні та металургії: зб. наук. пр. - Харків : НТУ "ХПІ", 2018. № 41 (1317). С. 91-102.

3. Левченко О. Г. Гігієна праці та виробнича санітарія у зварювальному виробництві. навч. посіб. Київ: «Основа», 2004.98c.

4. Демчина М. Вплив компонентів зварювального аерозолю на здоров'я людини.//https://cityadm.lviv.ua/news/society/emergency/233003-vplyv-komponentiv-zvariuvalnoho-aerozoliu-na-zdorovialiudyny. 24.06.2016

5. Трушкова Е. А., Ладная Е. В. Особенности профессиональных заболеваний электросварщиков при выполнении сварочных работ на производстве // Молодой ученый. 2016. №18.1. С. 25-27.

6. Колодій О. С. Охорона праці при виконанні робіт з електродугового зварювання / О. С. Колодій., 2018. $-16 \mathrm{c}$.

7. Березуцька Н. Л., Хондак I.I. Использование тестирующей программы «Исследование действия основных экологических законов» и информационно-обучающей программы по экологической безопасности в учебном процессе //Вісник НТУ «ХПІ» 2015. №11. С.164 - 170. 